\title{
Santorini Volcano and its Plumbing System
}

Timothy H. Druitt ${ }^{1}$, David M. Pyle ${ }^{2}$, and Tamsin A. Mather ${ }^{3}$

\begin{abstract}
Santorini Volcano is an outstanding natural laboratory for studying arc volcanism, having had twelve Plinian eruptions over the last 350,000 years, at least four of which caused caldera collapse. Periods between Plinian eruptions are characterized by intra-caldera edifice construction and lower intensity explosive activity. The Plinian eruptions are fed from magma reservoirs at 4-8 $\mathrm{km}$ depth that are assembled over several centuries prior to eruption by the arrival of high-flux magma pulses from deeper in the sub-caldera reservoir. Unrest in 20112012 involved intrusion of two magma pulses at about $4 \mathrm{~km}$ depth, suggesting a similar behaviour of the modern-day volcano to that prior to Plinian eruptions. Emerging understanding of Santorini's plumbing system will enable better risk mitigation at this highly hazardous volcano.
\end{abstract}

Keywords: Santorini caldera, Plinian eruption, Aegean arc, magma reservoir, volcanic unrest

\section{INTRODUCTION}

The volcanoes of the South Aegean Volcanic Arc pose an important hazard to the Eastern Mediterranean via ash fallout, pyroclastic flows and tsunamis (Jenkins et al. 2015). This is especially so for Santorini Volcano (FIG. 1A), which has had a long history of explosive volcanism (Druitt et al. 1999). There is a particular need to better understand the processes that lead up to eruptions at Santorini, and at arc volcanoes in general, in order to interpret geophysical and geochemical signals in times of unrest.

Owing to its well exposed products (FIG. 1B), its well documented historical activity, and its accessibility, Santorini has served as an internationally renowned laboratory for arc

\footnotetext{
${ }^{1}$ Clermont Auvergne University, CNRS, IRD, OPGC

Laboratory Magmas-Volcanoes

F-63000 Clermont-Ferrand, France

E-mail: tim.druitt@uca.fr

2 Department of Earth Sciences

University of Oxford

Oxford, UK

E-mail: David.Pyle@earth.ox.ac.uk

${ }^{3}$ Department of Earth Sciences

University of Oxford

Oxford, UK

E-mail: tamsin.mather@earth.ox.ac.uk
} 
volcanism. It is also a volcano of great historical interest. The classic study of Santorini by Ferdinand Fouqué (Fouque 1879) was one of the first to show that calderas form largely by vertical collapse, not explosive evacuation. More recently, field mapping and radiometric dating of the volcanic products have enabled reconstruction of the history of volcanism in detail (FIGS. 1C, 1D), and time-series petrological, geochemical and multi-isotopic data have been used to understand the origins and evolution of the magmas (Huijsmans et al. 1988; Druitt et al. 1999; Martin et al. 2010). Studies of laboratory phase equilibria experimentation on Santorini magmas, volatile contents of crystal-hosted melt inclusions, and mineral-melt equilibria have enabled reconstruction of the sub-caldera plumbing system (Cadoux et al. 2014; Andújar et al. 2015, 2016). An episode of unrest in 2011-2012 triggered a series of detailed geophysical and geochemical studies that provided new constraints on the nature of the magmatic system between eruptions (Newman et al. 2012; Parks et al. 2013, 2015).

\section{ERUPTIVE HISTORY}

Santorini has been active for over half-a-million years and has undergone multiple caldera collapses. It lies on stretched, $25 \mathrm{~km}$ thick continental crust within a NE-SW-trending transtensional rift zone connecting the extinct Christiana centre (to the SW), Santorini, and the 23 submarine centres of the Kolumbo chain (to the NE). The archipelago consists of three outer islands (FIG. 1C) that predate the Late Bronze Age (LBA; also called the "Minoan", at 3,600 BP) eruption, and two inner ones that post-date the LBA eruption. The earliest volcanic products (Akrotiri lavas, 650-550 ka) occur in the south, and consist mostly of amphibolebearing rhyolites similar to those at Christiana Volcano (Francalanci et al. 2005). Between 550 ka and $450 \mathrm{ka}$, a small stratovolcano, Peristeria, was constructed in the northern part of Santorini (FIG. 1C). From about 350 ka onwards, volcanism became highly explosive, with at least eleven Plinian eruptions between then and the LBA eruption (Druitt et al. 1999) (FIG. 1D). Each Plinian eruption had an initial fallout phase and, in most cases, also generated pyroclastic flows. Because many of the products are under the sea, the volumes of these eruptions are poorly constrained, but they each probably range from a few to a few tens of $\mathrm{km}^{3}$ of intermediate to silicic magma. The LBA eruption, one of the largest from Santorini, may have discharged as much as $86 \mathrm{~km}^{3}$ of rhyodacitic magma and rock debris, forming the present-day 300-400 m deep caldera (Johnston et al. 2014). Steep unconformities present in the cliff successions of Santorini have been interpreted as ancient caldera walls, with at least three events of caldera collapse (172 ka, $70 \mathrm{ka}$, and $22 \mathrm{ka}$ ) prior to the last one in the Late Bronze Age.

Plinian eruptions at Santorini are separated by "inter-Plinian" periods characterised by effusion of lavas that build lava shields, accompanied by weaker explosive activity (Vespa et al. 2006; Fabbro et al. 2013). The present-day Kameni edifice, of which the islands of Nea and 
Palaea Kameni form the subaerial summits, has grown during the 3,600 years since the LBA eruption. Today, the Kameni edifice reaches $470 \mathrm{~m}$ above the caldera floor (Nomikou et al. 2014). Thick sequences of lavas and thin tuffs intercalated within the ancient pyroclastic sequences of the caldera cliffs are the products of earlier inter-Plinian periods (FIGS. 1B, 1D). Like many other explosive volcanoes, Santorini has a repetitive three-fold cyclic behaviour: (1) Plinian eruption (with or without caldera collapse); (2) inter-Plinian edifice construction; (3) repose, leading up to the next Plinian eruption, with a return period of 10-30 ky. If the inter-Plinian activity is taken into account, Santorini has had an explosive eruption large enough to significantly impact the islands every few thousand years or less, although the frequency has not been constant.

\section{GENERATION AND STORAGE OF SILICIC MAGMA BENEATH THE CALDERA}

Santorini magmas range from basaltic to rhyolitic in composition. They are calc-alkaline to mildly tholeiitic in character and, apart from the early (650-550 ka) products, lack amphibole or other hydrous mineral phases. Geochemical modelling can reproduce the magmatic lineages through a combination of fractional crystallization and minor crustal contamination from a small range of chemically and isotopically distinct parental basalts that were presumably generated by partial melting of a mantle wedge that itself had been variably metasomatised by slab sediments (Bailey et al. 2009; Vaggelli et al. 2009; Klaver et al. 2016). Evidence for magma mixing in open-system magma reservoirs (e.g., compositionally variable magmatic components, banded pumices, quenched mafic enclaves) is common at Santorini, as at many other volcanoes.

Studies of laboratory phase equilibria of Santorini magmas, the volatile contents of crystalhosted melt inclusions, and mineral-melt equilibria have enabled reconstruction of the subcaldera plumbing system (FIG. 2) (Huijsmans et al. 1988; Cadoux et al. 2014; Andújar et al. 2015; 2016; Druitt et al. 2016). Cogenetic series of crystal-hosted melt inclusions have shown that the magmas are saturated in volatiles at upper-crustal pressures, as is typical of many island arcs. Moreover, Santorini silicic magmas are rich in halogens, particularly $\mathrm{Cl}$, and the LBA rhyodacitic magma may also have contained a free $\mathrm{H}_{2} \mathrm{O}+\mathrm{Cl}$-rich hydrosaline liquid (brine) phase prior to eruption (Cadoux et al. 2014). At Santorini, basalt with 2-4 wt\% $\mathrm{H}_{2} \mathrm{O}$ fractionates to mafic andesite at about $400 \mathrm{MPa}(\sim 16 \mathrm{~km}$ depth, close to the boundary between the lower and upper crust). Mafic andesite with $6 \mathrm{wt} \% \mathrm{H}_{2} \mathrm{O}$ then fractionates to silicic andesite, dacite and rhyodacite in the 400-200 MPa pressure range (about 16-8 km depth) (Andújar et al. 2015, 2016). Dacitic/rhyodacitic melts then migrate upwards to pre-eruptive chambers at 200-100 MPa (8-4 km depth), from which they are discharged during Plinian eruptions (Cadoux et al. 2014; Druitt et al. 2016). It appears from the melt-inclusion data that silicic magmas erupted during inter-Plinian periods were stored prior to eruption at lower 
pressures than the Plinian magmas, although neither the reasons nor implications of this are clear. An exception to this rule is the present-day Kameni dacitic magma, which appears from melt inclusions to reside prior to eruption at 4-6 km depth, near the top of the (probably now crystallized) LBA magma reservoir (FIG. 2). This agrees with depths estimated from mineralmelt equilibria on the Kameni magmas (Barton and Huijsmans 1986).

\section{BUILD-UP TO CALDERA-FORMING ERUPTIONS: PROCESSES AND TIMESCALES}

Recent petrological studies have shown that the large magma chambers that feed Plinian eruptions at Santorini are probably transient features on geological timescales. Magmas are now widely believed to be generated and incubated in bodies of crystal mush, from which they are extracted and accumulated in melt-dominated magma chambers prior to eruption (Bachmann and Huber 2016). Following over half-a-million years of magmatism, the crust beneath Santorini must be underlain by a thick, variably mushy, sub-caldera pluton in which the evolved melts that are ultimately erupted in Plinian events are generated and incubated.

Phenocrysts in magmas are commonly assumed to have formed in magma chambers by slow cooling over geologically long time periods. However, at Santorini this is not the case. By modelling of diffusive re-equilibration of chemical gradients in zoned phenocrysts of plagioclase, orthopyroxene, and clinopyroxene in pumices from the LBA eruption, it has been shown that the phenocrysts grew within only a few hundred years, and possibly only a few decades, of the eruption (Flaherty et al. 2018) (see FIG. 3 for an explanation of this method). Moreover, source-derived cores of the plagioclase phenocrysts contain melt inclusions trapped at higher pressures than those in the phenocryst rims (Druitt et al. 2016). By combining these observations with phase equilibria constraints for the LBA magma, it is inferred that phenocryst growth records one or more episodes of magma transfer from a source region of gabbroic to dioritic bulk composition in the 8-12 km depth range to a preeruptive magma chamber at 4-6 km depth, within a few centuries of the eruption (Cottrell et al. 1999; Druitt et al. 2012; Flaherty et al. 2018). Crystal growth was probably driven by a combination of vapour-saturated decompression during ascent and cooling in the new, upper crustal environment. Similar results have also been obtained for the earlier "Cape Riva" eruption (22 ka) (FIG. 1D), which suggests that this may be a general process at Santorini (Fabbro et al. 2018).

The new evidence suggests that the large magma chambers that feed Plinian eruptions and form calderas at Santorini are assembled on geologically short timescales by high-flux pulses of magma from deeper in the sub-caldera pluton. For example, the time-averaged rate of magma supply to the upper-crustal magma chamber prior to the LBA eruption has been 
estimated at 0.1 to $1 \mathrm{~km}^{3}$ per year, based on the phenocryst diffusion chronometry data, which is two to three orders of magnitude higher than the mean eruptive flux of magma during interPlinian periods (0.001 km³/y) (Druitt et al. 1999; Nomikou et al. 2014). A model is emerging that large eruptions at Santorini are preceded by events on two very different timescales: (1) prolonged generation of silicic magma deep in the sub-caldera pluton over many thousands of years, followed by (2) rapid transfer of that magma to the top of the sub-caldera pluton to form a transient magma chamber, from which eruption takes place a few centuries to a few decades afterwards. High-flux transfer events may provide a way of reconciling a continuous supply of basaltic magma and heat to the base of the crust with the intermittency of large silicic eruptions at Santorini. The mechanisms driving the rapid ascent of magma to form a shallow magma chamber are not yet understood.

\section{MODERN-DAY INTER-PLINIAN ACTIVITY}

Santorini is currently in an inter-Plinian phase. Over the 3,600 years since the LBA eruption, episodic effusive and minor explosive eruptions of dacitic magma have progressively built up the Kameni lava shield within the caldera, which now has a total volume of about $4 \mathrm{~km}^{3}$ (FIG. 4A). Little is known of the early development of the Kameni edifice, but it is likely that submarine lava extrusion began within a few hundred years of the LBA eruption and that a transient island emerged by 200 BCE (Nomikou et al. 2014).

Recent Kameni eruptions and their products have been very well studied (FIG. 4B). There are contemporary accounts of six subaerial eruptions since 1707. The most recent (but very small) eruption of Santorini was in 1950, three decades before the installation of the first instrumental monitoring networks on the islands. Based on contemporary accounts, all of the major historical eruptions have followed a similar pattern: a period of pre-eruptive deformation and seismicity that is accompanied by changes in the hydrothermal system, which leads to discoloration of the sea, followed by the slow extrusion of lava domes and thick, creeping dacitic lava flows. As the activity progresses, lava domes marking the vent become a focus for vigorous, but intermittent, explosive activity. Historical eruptions could last anywhere from 23 days to 1,723 days, and these eruptions could extrude lava at a typical rate of 2-4 $\mathrm{m}^{3} \mathrm{~s}^{-1}$. The durations and volumes of historical eruptions are generally proportional to the length of time elapsed since the previous eruption (Pyle and Elliott 2006; Nomikou et al. 2014).

Kameni lavas are glassy dacites of uniform composition, which led Barton and Huijsmans (1986) to infer that they were supplied from a long-lived and slowly evolving reservoir of silicic magma. All of the Kameni lavas also contain vesicular and glassy, crystal-rich enclaves 
of basaltic to andesitic composition. These are interpreted to be blobs of mafic magma that were mingled into the silicic magma shortly prior to eruption (Martin et al. 2006).

\section{THE VOLCANIC UNREST OF 2011-2012}

After 60 years with no detected earthquake swarms or sustained deformation across Santorini, an episode of unrest began in January 2011. Multiple small earthquakes were detected within the caldera, many located along the "Kameni Line", a fault system thought to have been responsible for delivering magma to the surface during previous eruptions (FIG. 5A) (Pyle and Elliott 2006). Geodetic data from permanent global positioning system stations and satellite interferometry confirmed that the whole of Santorini was deforming radially and inflating, with parts of northern Nea Kameni rising as much as $15 \mathrm{~cm}$ (Newman et al. 2012). Modelling of the deformation field showed that over the course of about 16 months, two pulses of volume increase with a total volume of 14-23 million cubic metres occurred at about $4 \mathrm{~km}$ depth beneath the northern caldera basin (FIGS. 5B, C) (Parks et al. 2015). This volume increase could have been caused by the intrusion of magma, gas, or a mixture of the two; distinguishing between these options is not possible based purely on geodetic data. If the inflation was purely from magma, then the volume injected in 2011-2012 was equivalent to $10 \%-50 \%$ of the volumes of the preceding dome-forming eruptions, and it appears to have been the only volumetrically significant shallow intrusion to have occurred since 1955 when records became available, shortly after the last eruption in 1950.

As well as deformation and earthquakes, there were small but distinct changes in the compositions and fluxes of gas emissions from the Kameni Islands in 2011-2012. The diffuse flux of soil $\mathrm{CO}_{2}$ increased subtly (and more significantly in the survey shortly following a seismic swarm), along with the concentrations of first $\mathrm{H}_{2}$, and later $\mathrm{CH}_{4}$, in fumarole gases, and the ratio of fumarolic ${ }^{3} \mathrm{He} /{ }^{4} \mathrm{He}$ (Parks et al. 2013; Tassi et al. 2013; Rizzo et al. 2015). Together, these observations are consistent with the arrival of a new batch of magma supplying a pulse of magmatic gas and heat to the shallow hydrothermal reservoir and promoting an increase in carbon dioxide emissions by exsolution from the magma, thermal breakdown of basement limestone and, maybe, increased permeability of the system following seismicity. The composition of the intruded magma is unclear. It is known from the He isotopic composition of gases emitted during the unrest that at least some of the magma was basaltic (Rizzo et al. 2015), but a mixture of dacite, basalt and basalt-derived gas cannot be ruled out if the dacite was largely degassed (see the soil gas ${ }^{222} \mathrm{Rn}-\delta^{13} \mathrm{C}$ systematics presented in Parks et al. 2013).

The observations imply that, whether Santorini is early in an inter-Plinian phase (such as the present day), or in the state of rapidly building up to a Plinian eruption (such as the LBA 
eruption), its shallow magma chamber is charged episodically by batches of deeper-derived magma. The durations of these events are short in comparison to the intervening periods of repose, and their timing is controlled by the dynamics of deeper magma reservoirs. Understanding these recharge events and how they relate to eruption triggering is a grand challenge in modern volcanology. Does gas release from the magma cause the seismicity, or vice versa? Does the gas release relieve reservoir pressure, and how does this relate to magma supply rate?

After 16 months, seismicity and deformation ceased, marking the end of the period of unrest. The inferred volume change in the shallow reservoir accounted for about 20 years equivalent of steady-state magma accumulation beneath the Kameni Islands, assuming a long-term, timeaveraged magma supply rate of about $10^{6} \mathrm{~m}^{3} \mathrm{y}^{-1}$ (i.e., $\sim 4 \mathrm{~km}^{3}$ in 3,600 years). The absence of an eruption presents a challenge to the intrusion-triggered model (Martin et al. 2006) for the historical eruptions of the Kameni Islands, and perhaps points to the need for a threshold rate of magma intrusion, or reservoir pressurisation, to be exceeded before eruption is triggered. The episode of unrest also reveals how little we understand of the behaviour of volcanoes in between eruptive episodes. There are records of precursors for all of the historical eruptions of the Kameni Islands; but none for "false alarm" events that did not lead to an eruption. The lack of records of non-eruptive unrest is likely to be a common feature of many volcanic systems and presents challenges for the interpretation of early stages of unrest.

\section{FUTURE ACTIVITY}

The progress made towards understanding the Santorini volcanic system illustrates the potential of combining geophysical measurements of unrest with careful petrological work and field mapping. It also illustrates the lessons that can be learned about caldera-forming eruptions by studying smaller-scale activity and unrest at systems with potential for eruptions on this scale. Our understanding of the system and past behaviour at Santorini allows us to make predictions about future hazards. For example, the correlation between the volumes of historical eruptions and the length of time elapsed since the previous eruption (Pyle and Elliott 2006; Nomikou et al. 2014) suggests that if an eruption took place soon, it would most likely be of the scale of that of 1925-1926, which produced a large lava flow. Further work is needed, however, to understand how and why the system transitions between smaller, more frequent activity and major Plinian eruptions.

\section{ACKNOWLEDGMENTS}

Lorella Francalanci, Alison Rust and Steve Sparks very kindly reviewed the manuscript. 


\section{REFERENCES}

Andújar J, Scaillet B, Pichavant M, Druitt TH (2015) Differentiation conditions of a basaltic magma from Santorini, and its bearing on the production of andesite in arc settings. Journal of Petrology 56: 765-794

Andújar J, Scaillet B, Pichavant M, Druitt TH (2016) Generation conditions of dacite and rhyodacite via the crystallization of an andesitic magma. Implications for the plumbing system at Santorini (Greece) and the origin of tholeiitic or calc-alkaline differentiation trends in arc magmas. Journal of Petrology 57: 1887-1920

Bachmann 0, Huber C (2016) Silicic magma reservoirs in the Earth's crust. American Mineralogist 101: 2377-2404

Bailey JC, Jensen ES, Hansen A, Kann ADJ, Kann K (2009) Formation of heterogeneous magmatic series beneath North Santorini, South Aegean island arc. Lithos 110: 20-36

Barton M, Huijsmans JPP (1986) Post-caldera dacites from the Santorini volcanic complex, Aegean Sea, Greece: an example of the eruption of lavas of near-constant composition over a 2,200 year period. Contributions to Mineralogy and Petrology 94: 472-495

Cadoux A, Scaillet B, Druitt TH, Deloule E (2014) Magma storage conditions of large plinian eruptions of Santorini Volcano (Greece). Journal of Petrology 55: 1129-1171

Cottrell E, Gardner JE, Rutherford MJ (1999) Petrologic and experimental evidence for the movement and heating of the pre-eruptive Minoan rhyodacite (Santorini, Greece). Contributions to Mineralogy and Petrology 135: 315-331

Druitt TH and 7 coauthors (1999) Santorini Volcano. Geological Society, London, Memoir 19: $165 \mathrm{pp}$

Druitt TH, Costa F, Deloule E, Dungan M, Scaillet B (2012) Decadal to monthly timescales of magma transfer and reservoir growth at a caldera volcano. Nature 482: 77-80

Druitt TH and 7 coauthors (2016) Magma storage and extraction associated with plinian and interplinian activity at Santorini Caldera (Greece). Journal of Petrology 57: 461-494

Fabbro GN, Druitt TH, Scaillet S (2013) Evolution of the crustal magma plumbing system during the build-up to the 22-ka caldera-forming eruption of Santorini (Greece). Bulletin of Volcanology 75, doi: 10.1007/s00445-013-0767-5

Fabbro GN, Druitt TH, Costa F (2018) Storage and eruption of silicic magma across the transition from dominantly effusive to caldera-forming states at an arc volcano (Santorini, Greece). Journal of Petrology 58: 2429-2464

Flaherty T and 5 coauthors (2018) Multiple timescale constraints for high-flux magma chamber assembly prior to the Late Bronze Age eruption of Santorini (Greece). Contributions to Mineralogy and Petrology 173, doi: 10.1007/s00410-018-1490-1

Fouqué FA (1879) Santorini and Its Eruptions [English translation by AR McBirney, 1999]. John Hopkins University Press, Baltimore and London, 495 pp

Francalanci L, Vougioukalakis GE, Perini G, Manetti P (2005) A west-east traverse along the magmatism of the south Aegean volcanic arc in the light of volcanological, chemical and isotope data. In: Fytikas M, Vougioukalakis GE (eds) The South Aegean Active Volcanic 
Arc: Present Knowledge and Future Perspectives. Developments in Volcanology 7, Elsevier, pp 65-111

Huijsmans JPP, Barton M, Salters VJM (1988) Geochemistry and evolution of the calc-alkaline volcanic complex of Santorini, Aegean Sea, Greece. Journal of Volcanology and Geothermal Research 34: 283-306

Jenkins SF and 7 coauthors (2015) Rapid emergency assessment of ash and gas hazard for future eruptions at Santorini Volcano, Greece. Journal of Applied Volcanology 4, doi: 10.1186/s13617-015-0033-y

Johnston EN, Sparks RSJ, Phillips JC, Carey S (2014) Revised estimates for the volume of the Late Bronze Age Minoan eruption, Santorini, Greece. Journal of the Geological Society 171: $583-590$

Klaver M, Davies GR, Vroon PZ (2016) Subslab mantle of African provenance infiltrating the Aegean mantle wedge. Geology 44: 367-370

Martin VM, Pyle DM, Holness MB (2006) The role of crystal frameworks in the preservation of enclaves during magma mixing. Earth and Planetary Science Letters 248: 787-799

Martin VM, Davidson J, Morgan D, Jerram DA (2010) Using the Sr isotope compositions of feldspars and glass to distinguish magma system components and dynamics. Geology 38: $539-542$

Newman AV and 10 coauthors (2012) Recent geodetic unrest at Santorini Caldera, Greece. Geophysical Research Letters 39, doi: 10.1029/2012GL051286

Nomikou P and 12 coauthors (2014) The emergence and growth of a submarine volcano: the Kameni islands, Santorini (Greece). GeoResJ 1-2: 8-18

Parks MM and 9 coauthors (2013) Distinguishing contributions to diffuse $\mathrm{CO}_{2}$ emissions in volcanic areas from magmatic degassing and thermal decarbonation using soil gas ${ }^{222} \mathrm{Rn}-\delta^{13} \mathrm{C}$ systematics: application to Santorini volcano, Greece. Earth and Planetary Science Letters 377-378: 180-190

Parks MM and 10 coauthors (2015) From quiescence to unrest: 20 years of satellite geodetic measurements at Santorini volcano, Greece. Journal of Geophysical Research: Solid Earth 120: 1309-1328

Pyle DM, Elliott JR (2006) Quantitative morphology, recent evolution, and future activity of the Kameni islands volcano, Santorini, Greece. Geosphere 2: 253-268

Rizzo AL and 6 coauthors (2015) New mafic magma refilling a quiescent volcano: evidence from He-Ne-Ar isotopes during the 2011-2012 unrest at Santorini, Greece. Geochemistry, Geophysics, Geosystems 16: doi: 10.1002/2014GC005653

Tassi F and 8 coauthors (2013) Geochemical and isotopic changes in the fumarolic and submerged gas discharges during the 2011-2012 unrest at Santorini caldera (Greece). Bulletin of Volcanology 75, doi: 10.1007/s00445-013-0711-8

Vaggelli G, Pellegrini M, Vougioukalakis G, Innocenti S, Francalanci L (2009) Highly Sr radiogenic tholeiitic magmas in the latest inter-Plinian activity of Santorini volcano, Greece. Journal of Geophysical Research: Solid Earth 114, doi: 10.1029/2008JB005936 
Vespa M, Keller J, Gertisser R (2006) Interplinian explosive activity of Santorini volcano (Greece) during the past 150,000 years. Journal of Volcanology and Geothermal Research 153: 262-286

\section{FIGURES}

Figure 1 (A) Aerial photograph of Santorini caldera (Greece) from the north. (B) Santorini caldera wall showing the thick tuff successions. The prominent light brown tuff is Lower Pumice 2 (LP2), the products of a Plinian eruption 172,000 years ago. It is overlain by a thick sequence of darker, stratified tuffs formed mainly during the subsequent inter-Plinian period (IP). (C) Simplified geological map of Santorini, with location map inset. (D) Simplified stratigraphic column, showing the products of Plinian eruptions in blue (mainly magmas of intermediate compositions) and red (mainly silicic magmas), and the products of inter-Plinian periods in brown, five of which are named. The two earliest products of the volcanic field are shown in green. Asterisk labels are as follows: ${ }^{*}=$ historically dated; ${ }^{* *}=$ dated by radiometric methods, principally $\mathrm{K}-\mathrm{Ar}$ and ${ }^{40} \mathrm{Ar} /{ }^{39} \mathrm{Ar}$; ${ }^{* * *}=$ dated by correlation with deep-sea ash layers. Abbreviations: $\mathrm{BCE}=$ before Common Era; $\mathrm{CE}=$ Common Era.

Figure 2 Interpretation of the crustal structure beneath Santorini caldera, based on published constraints from geodesy, mineral barometry, melt inclusion volatile barometry, and phase equilibria experiments. Numbered data sources as follows: 1 = Huijsmans et al. (1988); $2=$ Cottrell et al. (1999); 3 = Flaherty et al. (2018); 4 = Cadoux et al. (2014); 5 = Druitt et al. (2016); 6 = Andújar et al. (2015); 7 = Barton and Huijsmans (1986); 8 = Andújar et al. (2016); $9=$ Newman et al. (2012); 10 = Parks et al. (2015). Modified AFTER DruitT ET AL. (2016).

Figure 3 (A) Schematic showing the principle of the diffusion chronometry technique for a crystalline species exhibiting solid solution (for example, a plagioclase or a pyroxene). The crystal core (pyroxene 1, red) forms under a particular combination of pressure $(P)$, temperature $(T)$ and melt composition $(X)$. The crystal environment then changes, and the core is overgrown by a rim of different composition (pyroxene 2, yellow). The composite, zoned crystal then resides in the new environment for a period (residence time, $t_{\text {res}}$ ), during which diffusion tries to re-equilibrate the core with its rim and the surrounding melt. Elements that diffuse very fast will be completely re-equilibrated, while those that diffuse very slowly may not change much at all. Certain elements may, however, diffuse at a rate suitable for partial re-equilibration and production of a compositional gradient that can then be modelled using Fick's Law. If the diffusion coefficient of the element in question is known from laboratory experiments, and if the temperature of residence of the crystal can be constrained, then the time of residence ( $\left.t_{\text {res }}\right)$ of the crystal between stages 2 and 3 can be estimated. Volcanic eruption quenches the crystal and no further diffusion occurs. MODIFIED FROM DRUITT 
ET AL. (2012). (B) Backscattered electron image of an orthopyroxene crystal from the Late Bronze Age (LBA) eruption of Santorini. The yellow numbers are the crystal composition (Mg number, $\mathrm{Mg \#} \mathrm{=} \mathrm{atomic} 100 \times \mathrm{Mg} /[\mathrm{Mg}+\mathrm{Fe}])$, and the white numbers are diffusion timescales in years prior to eruption. Darker areas on the image are richer in $\mathrm{Mg}$; brighter areas are richer in Fe. The diffusion model on the right is for the red profile and assumed a step-function initial condition: it shows that the outer zone resided in contact with the inner zone at a petrologically constrained temperature of $860{ }^{\circ} \mathrm{C}$ for $55 \pm 8$ years prior to eruption quench. MODIFIED FROM FLAHERTY ET AL. (2018).

Figure 4 (A) Photograph looking SW of the present-day Kameni Islands. Dated lava flows are indicated. (B) Geological map of the present-day Kameni Islands. The map shows the different mapped lava flows. ModifIED FRom PYLE AND ELLIOTT (2006).

Figure 5 (A) Map of Santorini showing the distribution of epicentres of earthquakes during the period of caldera unrest during 2011-2012. The epicentres cluster along the Kameni Line, which is defined by an alignment of vents (blue dots) on Nea Kameni (NK) and probably reflects the existence of a fault at depth. The Kolumbo line, linking Santorini's volcanism with the Kolumbo chain to the NE, is also marked. The red star shows the centre of the 2011-2012 inflation. MODIFIED From PARKS ET AL. (2012). (B) A summary of the geodetic data (shown as subsurface volume change output from a joint inversion of global positioning system and interferometric synthetic aperture radar $\{\operatorname{InSAR}\}$ data) and seismic data (shown as cumulative seismic moment) from the 2011-2012 unrest. The geodetic signal was successfully modelled with two separate pulses of magma intruding (as illustrated by the red dashed line) into a chamber at $\sim 4 \mathrm{~km}$ depth surrounded by a viscoelastic shell. MODIFIED FROM PARKS ET AL. (2015). (C) Schematic perspective cross-section of the Santorini volcanic system illustrating the events of 2011-2012 and the possible subsurface processes that were occurring. Sketches are not to scale. (LEFT PANEL) The activity, characteristic of the state of the volcano since the last eruption in 1950, before the 2011-2012 unrest. Most seismicity was outside the caldera at Kolumbo Volcano, with minor fumarolic and hot spring activity on and around the Kameni Islands. (MIDDLE PANEL) A summary of the 2011-2012 unrest and the inferred activity at depth (see text for more details). (RIGHT PANEL) The processes surrounding the end of the period of unrest. The inflation occurred in two pulses, each terminated by an increased rate of seismic moment release which can be modelled by releasing pressure in the shallow chamber. Measurements suggested increased gas release just after the second of these seismic swarms which heralded the end of the unrest. The white ellipses are gas bubbles. 